TAHKIM, Jurnal Peradaban dan Hukum Islam. Vol.3 No.2 (0ktober, 2020) | ISSN : $2597-7962$

\title{
LARANGAN PERKAWINAN SEPERSUSUAN DITINJAU DARI PERSPEKTIF HUKUM ISLAM DAN MEDIS
}

\author{
Fahrul Fauzi \\ Fakultas Hukum Universitas Indonesia \\ fahrul.fauzi@ui.ac.id
}

\begin{abstract}
ABSTRAK
Islam memandang bahwa perkawinan bukanlah hubungan seperti kontrak keperdataan biasa melainkan akad yang sangat kuat atau perjanjian yang kokoh (mitsaaqaan ghaliizhaan). Perkawinan harus memperhatikan rukun, syarat, dan batasanbatasan agar dapat dikatakan sah menurut hukum. Salah satu batasan yang perlu diperhatikan adalah larangan perkawinan sepersusuan. Larangan perkawinan sepersusuan yang ditetapkan oleh Allah Swt dalam ayat Al-Quran pastilah memiliki alasan ilmiah. Artikel ini membahas larangan perkawinan sepersusuan ditinjau dari hukum Islam dan segi medis. Tinjauan hukum Islam untuk mengetahui bagaimana batasan-batasan sehingga seseorang dapat dikatakan sebagai saudara sepersusuan. Sedangkan tinjauan medis diperlukan untuk mengungkap alasan ilmiah mengapa larangan perkawinan sepersusuan ini dilarang oleh Allah Swt. Dalam penelitian ini, penulis menggunakan pendekatan yuridis normatif dengan menganalisis data sekunder, penelitian ini dapat dikatakan juga sebagai penelitian kepustakaan. Pendekatan penelitian ini didukung dengan menggunakan metode analisis deskriptif kualitatif.
\end{abstract}

\section{Kata Kunci: Larangan Perkawinan, Sepersusuan, Hukum Islam, Medis}

\section{ABSTRACT}

Islam considers that marriage is not a relationship like an ordinary civil contract but a very strong contract or a solid agreement (mitsaaqaan ghaliizhaan). Marriage must pay attention to harmony, conditions, and restrictions so that it can be said to be legal according to the law. One limitation that needs to be considered is the prohibition of the marriage of susuan relations (one breastfeed). The prohibition of the marriage of susuan relations stipulated by Allah in the Qur'an verse must have scientific reasons. This article discusses the prohibition of the marriages of susuan relations in terms of Islamic law and medical aspects. Review of Islamic Law to find out how the limits so that someone can be said as a susuan relations. While a medical review is needed to uncover the scientific reasons why the prohibition of the marriage of susuan relations is prohibited by Allah. In this study, the author uses a normative juridical approach by analyzing secondary data, this research can also be said as a library research. This research approach is supported by using descriptive qualitative analysis methods.

Keywords: Marriage Prohibition, Susuan Relations, Islamic Law, Medical 


\section{A. PENDAHULUAN}

Manusia pada dasarnya merupakan makhluk yang diciptakan oleh Allah Swt dengan kecenderungan seks (libido seksualitas) ${ }^{1}$. Memang benar bahwa sudah menjadi fitrah manusia memiliki hasrat untuk penyaluran kebutuhan biologis, namun hal tersebut perlu diberikan batas-batas kebolehan dan larangan untuk dilakukan sehingga penyelewengan hukum tidak akan terjadi. Sudah menjadi ketentuan alam bahwa semua makhluk itu berpasang-pasangan. Sama halnya manusia yang diciptakan dengan dua jenis kelamin yaitu pria dan wanita, dimana keduanya akan memiliki keinginan untuk membina rumah tangga bersama. Islam sebagai agama yang telah mengatur segalanya, sudah menyediakan cara untuk manusia agar dapat menyalurkan kebutuhan biologisnya sesuai dengan harkat manusia yaitu melalui perkawinan ${ }^{2}$.

Islam memandang bahwa perkawinan bukanlah hubungan seperti kontrak keperdataan biasa. Sangatlah tepat apabila perkawinan dipandang sebagai perjanjian yang kokoh atau akad yang sangat kuat (mitsaaqaan ghaliizhaan) ${ }^{3}$. Perkawinan merupakan sesuatu yang sakral serta luhur, dimana dengan melakukannya memiliki makna sebagai ibadah kepada Allah Swt, mengikuti sunnah Rasulullah Saw dan dilakukan atas dasar keikhlasan, tanggung jawab, serta mengikuti ketentuan hukum yang harus diperhatikan baik secara hukum agama maupun hukum nasional ${ }^{4}$. Melangsungkan perkawinan berarti melaksanakan ibadah ${ }^{5}$, sering pula disebut bahwa perkawinan adalah pintu untuk melakukan ibadah seumur hidup.

Allah Swt berfirman dalam QS. Ar-Rum (30): 21, "Dan di antara tanda-tanda kekuasaan-Nya ialah Dia menciptakan untukmu pasangan hidup dari jenismu sendiri, supaya kamu cenderung dan merasa tenteram kepadanya dan dijadikan-Nya di antaramu rasa kasih sayang. Seseungguhnya pada yang demikian itu menjadi tanda-

\footnotetext{
1 Agus Hermanto. Larangan Perkawinan Perspektif Fikih dan Relavansinya dengan Hukum Perkawinan di Indonesia. Muslim Heritage Vol.2 No.1 Mei-Oktober (2017), hlm. 125.

${ }^{2}$ Djalaluddin al-Ra'uf, Aturan Pernikahan dalam Islam (Jakarta: Jal Publishing, 2011), hlm. 11.

${ }^{3}$ Sayuti Thalib, Hukum Kekeluargaan Indonesia (Jakarta: UI-Press, 1986), hlm. 47.

${ }^{4}$ Wahyu Wibisana. Pernikahan dalam Islam. Jurnal Pendidikan Agama Islam - Ta'lim Vol.14 No.2 (2016), hlm. 193.

${ }^{5}$ Mohammad Daud Ali, Hukum Islam dan Peradilan Agama (Jakarta: PT RajaGrafindo Persada, 1997), hlm. 3 .
} 
tanda kebesaran-Nya bagi orang-orang yang berpikir."6 Perkawinan merupakan langkah awal untuk membentuk kehidupan berumah tangga yang sakinah, mawaddah, dan warahmah. Perkawinan juga merupakan salah satu cara untuk memelihara lima aspek Maqashid al-Khamsah atau dikenal pula dengan al-Maqasid al-Syariah yaitu memelihara agama (hifzal-din), jiwa (hifzal-nafs), akal (hifzal- 'aql), keturunan (hifzalnasab), dan harta (hifz al-mal).

Perkawinan harus dilakukan dengan memperhatikan syarat dan rukun tertentu agar perkawinan tersebut sah secara legal. Namun syarat dan rukun saja belumlah cukup untuk dapat membawa perkawinan tersebut menjadi sah, perlu juga diperhatikan ketentuan larangan perkawinan dimana telah diatur juga dalam Islam. Larangan perkawinan perlu diperhatikan karena konsekuensi dari dilanggarkan larangan perkawinan ini tidak jauh berbeda dengan pembatalan perkawinan. Hukum Islam membagi larangan perkawinan menjadi dua yaitu larangan perkawinan yang bersifat selamanya (mahram mu'abbad) dan yang bersifat sementara (mahram mu'aqqat). Larangan perkawinan untuk selamanya terbagi atas larangan perkawinan karena adanya pertalian keturunan (nasab), sepersusuan (radha'ah), dan persemendaan (mushaharah) ${ }^{7}$. Lebih rinci lagi pengaturan mengenai wanita yang tergolong mahram terdapat dalam QS. An-Nisa (4): 22-23, dalam ayat tersebut diatur empat belas wanita yang dilarang untuk dikawini.

Dengan demikian, tidak semua perempuan boleh dikawini, sebagian perempuan boleh untuk dikawini dan ada pula yang haram untuk dikawini ${ }^{8}$. Tulisan ini tidak akan mengulas satu persatu larangan perkawinan yang telah disebutkan di atas, melainkan akan berfokus pada larangan perkawinan karena sepersusuan (radha'ah). Tulisan ini akan meninjau larangan perkawinan karena sepesusuan dari prespektif hukum Islam dan juga kedokteran untuk mengetahui alasan ilmiah larangan perkawinan sepersusuan dari segi medis.

\footnotetext{
${ }^{6}$ Qs. ar-Rum (30): 21

${ }^{7}$ Amiur Nuruddin dan Azhari Akmal Tarigan, Hukum Perdata Islam di Indonesia: Studi Kritis terhadap Perkembangan Hukum Islam dari Fikih (Jakarta: Prenada Media Group, 2006), hlm. 145.

${ }^{8}$ Rasyidin Imran. Larangan Kawin Karena Pertalian Sesusuan Dalam Perspektif Fikih dan Kompilasi Hukum Islam. Tathwir Jurnal Pengembangan Masyarakat Vol.1 No.1 (2018), hlm. 28.
} 


\section{B. METODE PENELITIAN}

Pendekatan yang digunakan dalam penelitian ini adalah pendekatan yuridis normatif (normative juridical approach). Penelitian ini mengkaji beberapa data sekunder, termasuk bahan-bahan hukum sekunder baik itu peraturan perundangundangan maupun norma-norma positif lain yang mengatur masalah larangan perkawinan karena sepersusuan. Penelitian ini dapat juga disebut sebagai penelitian kepustakaan yaitu penelitian terhadap data sekunder ${ }^{9}$. Data-data sekunder yang digunakan antara lain peraturan perundang-undangan yaitu UU Perkawinan, Kompilasi Hukum Islam, dan Kitab Undang-Undang Hukum Perdata yang didukung beberapa bahan buku bacaan dan jurnal yang secara umum maupun spesifik membahas permasalahan perkawinan sepersusuan ini. Penelitian ini menggunakan metode analisis deskriptif kualitatif, yaitu mengambil suatu penilaian secara tidak langsung dengan cara menarik kesimpulan yang dituangkan dalam bentuk pernyataan atau tulisan ${ }^{10}$.

\section{PEMBAHASAN}

\section{Tinjauan Hukum Nasional Terhadap Perkawinan}

Kitab Undang-Undang Hukum Perdata (KUHPerdata) sebagai salah satu sumber hukum perkawinan sebelum adanya Undang-Undang Nomor 1 Tahun 1974 tentang Perkawinan (UU Perkawinan) tidak memberikan pengertian tentang apa itu perkawinan. Pasal 26 KUHPerdata hanya mengartikan perkawinan dari segi perdatanya. Sehingga dalam KUHPerdata, tidak ada penjelasan tentang definisi perkawinan, siapa yang boleh melangsungkan perkawinan, posisi pihak dalam perkawinan, dan apa tujuan dari

${ }^{9}$ Soerjono Soekanto dan Sri Mamudji, Penelitian Hukum Normatif, Suatu Tinjauan Singkat (Jakarta: Rajawali, 1985), hlm. 15.

${ }^{10}$ Lexy J. Moleong, Metode Penelitian Kualitatif (Bandung: Remaja Rosda Karya, 2011), hlm. 248. 
dilangsungkannya perkawinan ${ }^{11}$. Saat itu, guna mengisi kekosongan hukum dipakailah doktrin sebagai alternatif dalam mendefinisikan perkawinan. Prof. Subekti sebagai salah satu sarjana pada masa itu mendefinisikan perkawinan sebagai pertalian yang sah antara seorang lelaki dan seorang perempuan untuk waktu yang lama ${ }^{12}$.

UU Perkawinan merupakan suatu unifikasi hukum tentang perkawinan yang sifatnya nasional dan berlaku bagi seluruh warga negara Indonesia. Beda halnya dengan KUHPerdata yang tidak memberikan definisi dari perkawinan, UU Perkawinan secara tegas memberikan pengertian perkawinan. Diatur dalam Pasal 1 bahwa "perkawinan adalah ikatan lahir batin antara seorang pria dengan seorang wanita sebagai suami isteri dengan tujuan membentuk keluarga/rumah tangga yang bahagia dan kekal berdasarkan ketuhanan yang maha esa".

Pengertian perkawinan di atas mengatakan bahwa perkawinan adalah sebuah ikatan (perikatan). Pertanyaan yang muncul dan perlu dijawab adalah apakah ikatan dalam perkawinan sama dengan pengertian perjanjian pada umumnya? Berikut akan diberikan tabel perbedaan mengenai ikatan perjanjian biasa dan ikatan yang dimaksud dalam perkawinan.

\begin{tabular}{|c|c|c|}
\hline No. & Perikatan pada umumnya & Perkawinan \\
\hline 1 & $\begin{array}{l}\text { Perjanjian berlaku pada pihak-pihak } \\
\text { yang bersangkutan }\end{array}$ & Perkawinan berlaku bagi setiap orang \\
\hline 2 & $\begin{array}{l}\text { Perjanjian dilakukan oleh pihak-pihak } \\
\text { yang berkepentingan }\end{array}$ & $\begin{array}{l}\text { Perkawinan dilangsungkan oleh pejabat } \\
\text { negara (Kantor Catatan Sipil/Kantor } \\
\text { Urusan Agama) }\end{array}$ \\
\hline 3 & $\begin{array}{l}\text { Perjanjian mengenal adanya asas } \\
\text { kebebasan berkontrak, sehingga isi } \\
\text { perjanjian bebas ditentukan pihak }\end{array}$ & $\begin{array}{l}\text { Perkawinan tidak dapat secara bebas } \\
\text { menentukan syarat dan isi dari } \\
\text { perkawinan karena telah diatur dalam } \\
\text { undang-undang }\end{array}$ \\
\hline 4 & $\begin{array}{l}\text { Segala hak dan kewajiban yang } \\
\text { timbul dari adanya perjanjian dapat } \\
\text { dialihkan pada orang lain }\end{array}$ & $\begin{array}{l}\text { dan kewajiban yang timbul } \\
\text { vinan melekat hanya kepada } \\
\text { melakukan perkawinan saja }\end{array}$ \\
\hline 5 & 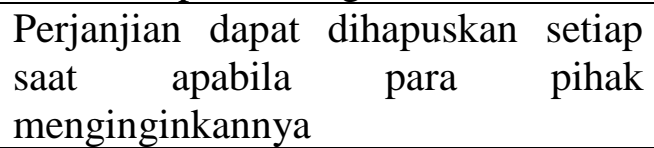 & $\begin{array}{l}\text { Perkawinan hanya putus karena } \\
\text { kematian atau alasan yang diatur secara } \\
\text { limitatif dalam undang-undang }\end{array}$ \\
\hline
\end{tabular}

${ }^{11}$ Akhmad Budi Cahyono dan Surini Ahlan Sjarif, Mengenal Hukum Perdata (Jakarta: CV Gitama Jaya, 2008), hlm. 42.

${ }^{12}$ Subekti, Pokok-Pokok Hukum Perdata (Jakarta: PT Intermasa, 1984), hlm. 23. 
TAHKII, Jurnal Peradaban dan Hukum Islam. Vol.3 No.2 (0ktober, 2020) | ISSN : 2597-7962

Tabel 1.

Perbedaan perkawinan dengan perikatan pada umumnya

Karena perbedaan-perbedaan di atas maka dapat disimpulkan bahwa perkawinan berbeda dengan perjanjian yang diatur dalam Buku III KUHPerdata. Perkawinan lebih merupakan lembaga yang memberikan seseorang suatu status tertentu. Mengingat pula pengaturan akan hukum perkawinan yang sifatnya tertutup, dimana tidak digantungkan hanya pada kehendak bebas para pihak sebagaimana perjanjian pada umumnya ${ }^{13}$.

Dilangsungkannya perkawinan harus memperhatikan syarat materil dan syarat formil agar dapat dikatakan sah. Syarat materil merupakan syarat yang berkaitan dengan pribadi si calon mempelai pria maupun wanita. Syarat formil ialah syarat yang berkenaan formalitas yang menjadi patokan untuk diikuti calon mempelai pria maupun wanita, meliputi pada saat sebelum ataupun pada saat dilakukannya perkawinan. Syarat materil dibagi menjadi dua, yaitu syarat materil umum dan syarat materil khusus. Syarat materil umum diatur dalam Pasal 6 dan 7 UU Perkawinan, dimana harus ada persetujuan dari kedua belah pihak calon mempelai, batas umur untuk dilangsungkannya perkawinan untuk suami maupun isteri adalah 19 tahun $^{14}$, tidak dalam status perkawinan, memperhatikan waktu tunggu (dalam islam dikenal masa iddah).

Selanjutnya mengenai syarat materil khusus lebih menitikberatkan pada izin dan larangan. Untuk dilangsungkannya perkawinan, diperlukan izin dari orangtua maupun wali dengan tetap memperhatikan mengenai larangan perkawinan yang diatur dalam Pasal 8 UU Perkawinan. Berikutnya syarat formil perkawinan dibagi menjadi dua yaitu sebelum dan pada saat dilangsungkannya perkawinan yang diatur dalam Peraturan Pemerintah No. 9 Tahun 1975. Kemudian mengenai syarat formil sebelum dilangsungkannya perkawinan yaitu perkawinan harus terlebih dahulu para mempelai melapor atau memberitahukan pada pegawai KCS atau KUA. Pemberitahuan mesti disertai surat pembuktian yang diatur oleh undang-undang, dan perkawinan baru dapat

${ }^{13}$ Cahyono, Mengenal..., hlm. 46.

${ }^{14}$ Ketentuan awalnya batas umur wanita untuk menikah adalah 16 tahun, namun setelah berlakunya UU No 16 Tahun 2019 tentang Perubahan Atas UU Perkawinan, batas umur untuk wanita adalah sama dengan pria yaitu 19 tahun. 
dilangsungkan setelah tenggang waktu 10 hari yang dihitung dari tanggal pemberitahuan. Sedangkan syarat formil pada saat dilangsungkan perkawinan adalah perkawinan harus dilakukan di hadapan pegawai pencatat nikah, perkawinan wajib dihadiri oleh dua orang saksi, setelah perkawinan dilangsungkan akan dilakukan penandatanganan akta perkawinan yang membuat perkawinan sah menurut hukum negara ${ }^{15}$.

\section{Tinjauan Hukum Islam Terhadap Perkawinan}

Perkawinan merupakan perbuatan hukum yang dapat dilakukan oleh mukallaf apabila telah memenuhi syarat. Definisi perkawinan dalam hukum Islam yaitu pernikahan atau akad yang sangat kuat (mitsaaqaan ghaliizhaan) guna menaati perintah Allah Swt dan pelaksanaannya merupakan ibadah yang memiliki tujuan agar dapat membentuk kehidupan rumah tangga yang sakinah, mawadah, dan rahmah $^{16}$. Frasa nikah secara bahasa memiliki definisi 'berkumpul menjadi satu', sedangkan dari segi syara' nikah adalah suatu akad yang berisi pembolehan untuk melakukan persetubuhan dengan 'lafadz inkahin' atau 'tazwizin'. Syaikh Zainuddin bin Abdul Aziz Al-Malibrary berpendapat bahwa kata nikah secara hakiki memiliki arti akad dan secara majazi berarti bersenggamaan ${ }^{17}$.

Para fukaha pengikut mahzab Syafi'i, Hanafi, Maliki, maupun Hambali pada umumnya mengartikan perkawinan sebagai akad yang mengakibatkan kebolehan (bagi lelaki untuk berhubungan kelamin dengan wanita) dengan (diawali saat akad) lafazh nikah atau kawin, atau makna yang serupa dengan kedua kata tersebut ${ }^{18}$.

Sajuti Thalib mengatakan perkawinan merupakan perjanjian suci untuk membentuk keluarga antara seorang laki-laki dan perempuan. Perkawinan dan perkawinan saat ini sering dibedakan artinya oleh masyarakat, akan tetapi pada prinsipnya perkawinan dan

\footnotetext{
${ }^{15}$ Cahyono, Mengenal Hukum..., hlm. 47-50.

${ }^{16}$ Neng Djubaedah, Sulaikin Lubis, dan Farida Prihatini, Hukum Perkawinan Islam di Indonesia (Jakarta: PT Hecca Mitra Utama, 2005), hlm. 33.

17 Syaikh Zainuddin bin Abdul Aziz Al-Malibrary, Fatchul Mu’in, terj. Aliy As'sd (Kudus: Menara Kudus, 1979), hlm. 1.

212. ${ }^{18}$ Abdurrahman Al-Jaziri, al-Fiqh 'ala Madzahib al-Arba'ah (Beirut: Dar al-Fikr, 1986), hlm.
} 
TAHKIM, Jurnal Peradaban dan Hukum Islam. Vol.3 No.2 (0ktober, 2020) | ISSN : $2597-7962$

pernikahan hanya berbeda dalam menarik akar katanya saja ${ }^{19}$. Prof. Mohammad Daud Ali mengatakan bahwa perkawinan merupakan lembaga yang suci, hal tersebut dapat dilihat dari tata cara melangsungkannya, tata hubungan suami isteri, bahkan cara melakukan dan menyelesaikan perceraian ${ }^{20}$.

Perkawinan merupakan fitrah ilahi sebagaimana difirmankan dalam QS. Ar-Rum (30): 21, "Dan di antara tanda-tanda kekuasaan-Nya ialah Dia menciptakan untukmu isteri-isteri dari jenismu sendiri, supaya kamu cenderung dan merasa tenteram kepadanya, dan dijadikan-Nya diantaramu rasa kasih dan sayang. Sesungguhnya pada yang demikian itu benar-benar terdapat tanda-tanda bagi kaum yang berpikir." 21 Ayat yang lain dalam QS. An-Nisa (4): 1, “Berbaktilah kamu kepada Allah yang atas (dengan) nama-Nya kamu saling meminta untuk menjadi pasangan hidup." 22 Selanjutnya 82 hari sebelum Rasulullah Saw wafat beliau berpesan "Takutlah kamu kepada Allah mengenai urusan wanita, karena kamu telah mengambil mereka (dari orang tuanya) dengan amanat Allah"23.

Rasulullah Saw memerintahkan orang-orang yang telah memiliki kesanggupan untuk melakukan perkawinan karena perkawinan akan menjaga seseorang dari perbuatan-perbuatan yang dilarang oleh Allah Swt. Dalam sunnah qauliyah (sunnah dalam bentuk perkataan), Rasulullah Saw berkata "Barang siapa yang kawin berarti ia telah melaksanakan separuh (ajaran) agamanya, yang separuh lagi hendaklah ia taqwa kepada Allah Swt"24. Rasulullah Saw sangat menganjurkan bagi orang yang ingin menikah namun belum siap bekal baik fisik maupun nonfisik untuk berpuasa, karena berpuasa akan memberikan kekuatan atau menahan seseorang itu untuk melakukan tindakan yang keji (perzinaan) ${ }^{25}$.

Apabila ditinjau dari segi al-ahkam al-khamsah (lima ukuran untuk menilai perbuatan manusia dan benda), asal kaidah dari perkawinan adalah ja'iz, mubah, ibahah

${ }^{19}$ Sudarsono, Hukum Keluarga Nasional (Jakarta: Rineka Cipta, 1997), hlm. 62.

${ }^{20}$ Ali, Hukum Islam ..., hlm. 2.

${ }^{21}$ Qs. ar-Rum (30): 21.

${ }^{22}$ Qs. an-Nisa (4): 1.

${ }^{23}$ Ali, Hukum Islam ..., hlm. 2.

${ }^{24}$ Ali, Hukum Islam ..., hlm. 3.

${ }^{25}$ Zainuddin Ali, Hukum Perdata Islam di Indonesia (Jakarta: Sinar Grafika, 2007), hlm. 7. 
yang berarti kebolehan. Namun apabila terjadi perubahan 'illat (motif atau alasan), sifat ja'iznya dapat berubah menjadi sunnat, wajib, makruh, ataupun haram $^{26}$. Sebagai contoh, perkawinan menjadi sunnah apabila orang yang ingin melakukan perkawinan itu sudah cukup umur dan telah wajar untuk berumah tangga. Perkawinan dapat menjadi wajib apabila seseorang dipandang telah sangat mampu untuk mendirikan rumah tangga dan sanggup memenuhi kebutuhan, serta telah matang pertumbuhan rohani dan jasmaninya. Selanjutnya perkawinan dapat menjadi makruh apabila dilakukan oleh seorang yang belum cukup umur dan belum mampu menafkahi dan mengurus rumah tangga. Terakhir, dapat menjadi haram apabila, seorang melakukan perkawinan dengan niat ingin menyiksa atau menganiaya pasangannya ${ }^{27}$.

Berdasarkan hal yang telah dikemukakan di atas bahwa hukum Islam memandang perkawinan sebagai salah satu perintah agama kepada siapa saja yang sudah sanggup dan memenuhi syarat untuk melangsungkannya. Perkawinan dilakukan karena dapat meminimalisir perbuatan seseorang dari kemaksiatan yang salah satunya adalah perzinaan.

\section{Larangan Perkawinan Dalam Hukum Islam}

Perkawinan yang telah memenuhi rukun dan syarat yang ditentukan, belum tentu mutlak menjadi sah, karena perlu diperhatikan lagi satu hal yaitu apakah perkawinan yang dilakukan telah lepas dari segala penghalang? Halangan yang dimaksud di sini ialah larangan perkawinan. Larangan perkawinan mengatur seorang pria atau wanita dengan siapa saja mereka dilarang untuk melakukan perkawinan. Mengapa hal ini perlu untuk diperhatikan? Karena dalam hukum perkawinan Islam dikenal asas selektivitas, maksud asas ini yaitu apabila seorang pria atau wanita hendak melakukan perkawinan, maka harus diseleksi terlebih dahulu dengan siapa mereka boleh menikah dan dengan siapa mereka dilarang untuk menikah ${ }^{28}$.

\footnotetext{
${ }^{26}$ Khotibul Umam dan Angger Sigit Pramukti, Hukum Islam dan Acara Peradilan Agama (Tangerang Selatan: Universitas Terbuka, 2015), hlm. 6.9.

${ }^{27}$ Ali, Hukum Islam ..., hlm. 4-5.

${ }^{28}$ Mohd. Idris Ramulyo, Hukum Perkawinan Islam: Suatu Analisis dari UU No. 1 Tahun 1974 dan Kompilasi Hukum Islam (Jakarta: Bumi Aksara, 1996), hlm. 34.
} 
Setiap pria muslim pada dasarnya dapat menikahi atau mengawini wanita manapun yang disukainya. Namun prinsip ini tidak berlaku mutlak, karena dalam Islam ada pembatasan yang perlu diperhatikan bagi dua insan yang ingin membangun rumah tangga. Batasan-batasan yang dimaksud di sini diatur secara jelas dalam QS. Al-Baqarah dan QS. An-Nisa. Penggolongan tersebut antara lain yaitu (1) larangan nikah berbeda agama; (2) larangan nikah sedarah; (3) larangan nikah sepersusuan; (4) larangan nikah karena semenda; dan (5) larangan nikah dengan wanita yang sudah memiliki suami.

Pertama, mengenai larangan perkawinan karena perbedaan agama, hal ini dicantumkan secara tegas dalam QS. Al-Baqarah (2): 221 yang artinya, “Dan janganlah kamu menikahi wanita-wanita musyrik, sebelum mereka beriman. Sesungguhnya wanita budak yang mukmin lebih baik dari wanita musyrik, walaupun dia menarik hatimu. Dan janganlah kamu menikahkan orang-orang musyrik (dengan wanita-wanita mukmin) sebelum mereka beriman. Sesungguhnya budak yang mukmin lebih baik dari orang musyrik, walaupun dia menarik hatimu. Mereka mengajak ke neraka, sedang Allah mengajak ke surga dan ampunan dengan izin-Nya. Dan Allah menerangkan ayat-ayatNya (perintah-perintah-Nya) kepada manusia supaya mereka mengambil pelajaran." 29 Walaupun dalam QS. Al-Maidah (5): 5 ada pengecualian khusus untuk laki-laki muslim yang hendak mengawini wanita ahlul kitab. Namun dalam praktik, karena lebih banyak mudharat-nya perkawinan laki-laki muslim dengan wanita ahli kitab menjadi masalah.

Kedua, mengenai larangan perkawinan karena pertalian darah, hal ini ditegaskan dalam QS. An-Nisa (4): 23, dimana dalam ayat tersebut dijelaskan bahwa pria dilarang untuk mengawini ibu, anak atau anak-anak perempuan, saudara perempuan, saudara perempuan ayah (atau bibi), saudara perempuan ibu (atau bibi), anak perempuan saudara laki-laki (ponakan), dan anak perempuan saudara perempuan (ponakan) ${ }^{30}$.

Ketiga, perihal larangan perkawinan karena sepersusuan akan dibahas lebih mendetail pada bagian selanjutnya dalam artikel ini. Keempat, mengenai larangan nikah dengan yang memiliki hubungan semenda. Hubungan semenda ialah hubungan kekeluargaan yang muncul karena pernikahan yang telah terjadi sebelumnya. Sama

${ }^{29}$ Qs. al-Baqarah (2): 221.

${ }^{30}$ Qs. an-Nisa (4): 23. 
seperti larangan perkawinan karena pertalian darah, dalil mengenai larangan perkawinan semenda juga diatur dalam QS. An-Nisa (4): 23, dimana dilarang bagi seorang lelaki menikahi ibu dari isteri (mertua), anak tiri, isteri dari anak (menantu), dua orang wanita bersaudara sekaligus, dan perempuan yang telah dinikahi oleh bapak (ibu tiri).

Kelima, perihal larangan perkawinan dengan perempuan yang telah bersuami. Dalam QS. An-Nisa (4): 24 dijelaskan bahwa laki-laki dilarang untuk mengawini perempuan yang terikat dalam ikatan nikah dengan laki-laki lain (sedang bersuami). Apabila dilihat dari sisi perempuan, bentuk pelarangan ini merupakan pencegahan agar tidak terjadi perempuan yang bersuami lebih dari satu (poliandri).

Berdasarkan beberapa larangan diatas apabila dikelompokan dan dikembangkan maka akan didapat garis besar dari pelarangan tersebut. Yaitu larangan yang berlaku untuk selama-lamanya (tahrim muabbad) dan larangan yang berlaku dalam jangka waktu tertentu saja (tahrim muwaqqat). Yang termasuk dalam tahrim muabbad dalam hal ini yaitu larangan perkawinan karena hubungan keturunan (nasab), larangan perkawinan karena telah ada perkawinan sebelumnya (mushaharah), dan larangan perkawinan karena sepersusuan (radha'ah). Sedangkan larangan perkawinan yang hanya berlaku dalam jangka waktu tertentu atau tahrim muwaqqat terjadi karena sebab-sebab tertentu. Contohnya mengawini dua orang perempuan kakak-beradik hal ini dilarang apabila dilakukan pada saat yang bersamaan, namun diperbolehkan apabila dilakukan pada waktu yang berbeda, semisal kakak perempuan yang telah dinikahi terlebih dahulu meninggal dunia, sehingga suami dari kakak perempuan tersebut dapat menikahi adiknya.

Larangan perkawinan yang dimaksud dalam hukum perkawinan Islam ini, di dalam fikih disebut sebagai mahram (orang yang haram untuk dinikahi). Di kalangan masyarakat Indonesia penggunaan istilah ini kurang tepat, masyarakat sering menyamakan dengan istilah muhrim. Kata muhrim digunakan untuk menyebut orang yang sedang ihram ${ }^{31}$.

\footnotetext{
${ }^{31}$ Abdul Aziz Dahlan, Ensiklopedi Hukum Islam (Jakarta: Ikhtiar Baru Van Hoeve, 1996), hlm. 1049.
} 
TAHKIM, Jurnal Peradaban dan Hukum Islam. Vol.3 No.2 (0ktober, 2020) | ISSN : 2597-7962

\section{Tinjauan Hukum Islam Terhadap Perkawinan Saudara Sepersusuan}

Sepersusuan dalam bahasa arab ialah radha'ah yang mana merupakan bentuk mashdar dari kata radha'a atau radhaatshadya maknanya dia menyusu atau menetek susu ibu. Secara terminologi, rada'ah adalah suatu nama untuk isapan atau sedotan dari alsadyu (puting susu), baik kepada manusia maupun pada binatang. Pengertian yang telah dituliskan sebelumnya dapat diambil dua benang merah mengenai radha'ah yaitu 1) isapan langsung dari $a l$-sadyu, dengan demikian apabila air susu itu diperah lalu dikonsumsi pada bayi, maka hal tersebut bukanlah sebagai radha'ah. 2) siapa saja yang menetek atau menyusu, baik itu sudah dewasa atau masih bayi, bisa kepada manusia maupun hewan juga disebut sebagai radha' $a h^{32}$.

Ayat Al-Quran yang mengatur mengenai larangan perkawinan karena sepersusuan diatur dalam QS. An-Nisa (4): 23, yang mengatur bahwa seorang laki-laki dilarang untuk mengawini ibu susumu dan dilarang pula mengawini saudara perempuan sepersusuan ${ }^{33}$.

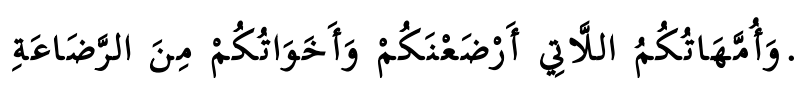

Walaupun dalam QS. An-Nisa (4): 23 hanya menyatakan wanita yang dilarang untuk dinikahi karena sepersusuan itu ibu dan saudara-saudara sepersusuan saja, namun fukaha berpendapat bahwa yang dilarang tidak hanya sebatas ibu dan saudara sepersusuan. Berlaku juga seperti halnya ibu dan saudara kandung, di pihak ibu kandung misalnya, yang termasuk haram dinikahi mencakup nenek ke atas dan ke bawah anak perempuan dan seterusnya, dan ke samping saudara perempuan. Demikian halnya dengan perempuan yang mempunyai hubungan darah dengan ibu susuan dan saudara sepersusuan.

Maka dengan demikian hubungan sepersusuan yang dilarang untuk dinikahi ialah 1) ibu susuan (ibu rada'/murdi'ah), yaitu seorang ibu yang pernah menyusui seorang anak. 2) nenek susuan, yaitu ibu dari murdi'ah atau ibu susuan atau ibu dari suami si murdi'ah.3) bibi susuan, yakni saudara perempuan ibu susuan atau saudara atau saudara perempuan suami dari ibu susuan dan seterusnya ke atas. 4) keponakan susuan

\footnotetext{
${ }^{32}$ Imran. Larangan Kawin ......, 29.

${ }^{33}$ Qs. an-Nisa (4): 23.
} 
TAHKIM, Jurnal Peradaban dan Hukum Islam. Vol.3 No.2 (0ktober, 2020) | ISSN : $2597-7962$

perempuan, yaitu anak perempuan dari saudara ibu susuan. Dan 5) saudara susuan perempuan, saudara seayah kandung maupun seibu.

Pasal 8 huruf d UU Perkawinan menyebutkan bahwa perkawinan dilarang antara dua orang yang berhubungan susuan, yaitu orang tua susuan, anak susuan, saudara susuan dan bibi/paman susuan. Diatur juga dalam Pasal 39 ayat (3) Kompilasi Hukum Islam tentang larangan dilangsungkannya perkawinan sepersusuan. Dinyatakan bahwa seorang pria dilarang menikahi

(1) dengan wanita yang menyusuinya (ibu susuan) dan seterusnya menurut garis keturunan ke atas;

(2) dengan seorang wanita sepersusuan (saudara sepersusuan) dan seterusnya menurut garis keturunan ke bawah;

(3) dengan seorang wanita saudara sesusuan, dan kemenakan sesusuan ke bawah;

(4) dengan seorang wanita bibi sesusuan dan nenek bibi sesusuan ke atas;

(5) dengan anak yang disusui oleh isterinya dan keturunannya.

Sayuti Thalib dalam buku 'Hukum Kekeluargaan Indonesia' berpendapat bahwa hubungan sepersusuan menjadikan seseorang memiliki hubungan kekeluargaan yang sedemikian dekatnya. Mereka yang sesusuan itu telah menjadi saudara dalam pengertian hukum perkawinan, dan disebut saudara sesusuan. Akan tetapi pendekatan ke dalam saudara sepersusuan itu tidak menjadikan hubungan persaudaraan sedarah untuk terjadinya saling mewaris karena sedarah dalam hukum kewarisan ${ }^{34}$.

Ulama berpendapat larangan perkawinan sepersusuan atau radha'ah jika sampainya air susu ibu susuan ke dalam perut bayi yang belum mencapai usia dua tahun kalendar hijriyah dengan metode tertentu. Baik laki-laki maupun perempuan yang mempunyai mahram dari jalur sepersusuan mempunyai keistimewaan dan kekebalan hukum sebagaimana mahram yang terbentuk dari jalur nasab. Dimana diantara mereka (mahram rada') tidak diperbolehkan untuk saling menikahi ${ }^{35}$.

Beberapa ulama juga memberikan penjelasan dan pembatasan, mengenai larangan waktunya menyusu dan berapa lamanya menyusu serta berapa banyak air susu si ibu

\footnotetext{
${ }^{34}$ Thalib, Hukum Kekeluargaan ...., hlm. 51-52.

${ }^{35}$ Hermanto. Larangan Perkawinan ....., hlm. 129.
} 
setiap kali menyusu itu, baru berakibat menjadikan orang yang disusui tersebut menjadi saudara sesusuan karena hukum.

Dilihat dari segi waktu terjadinya penyusuan, para ahli agama sepakat bahwa si anak yang disusui memang masih butuh air susu ibu untuk dijadikan sumber makanan pokoknya untuk bahan pengembangan jasmaninya. Jadi harus diperhatikan bahwa si anak memang masih dalam masa menyusu atau masih bayi. Sehingga apabila masa penyusuan itu terjadi pada saat si anak sudah lumayan besar atau bahkan dewasa, hal tersebut tidak ada artinya lagi untuk menjadikan mereka saudara karena sepersusuan.

Mengenai berapa kali seorang bayi menyusu sehingga memiliki implikasi menjadi saudara sepersusuan beberapa ulama berbeda pendapat. Menurut Imam Syafi'i dan Imam Ahmad, untuk dapat dikatakan menjadi orang saudara sepersusuan ialah lima kali menyusu penuh hingga kenyang setiap kali bayi itu menyusu. Ulama yang lain, yaitu pihak mazhab Hanafi dan Mailiki berpendapat bahwa menyusu sedikit atau banyak akan sama akibatnya menjadikan bayi itu memiliki ikatan sepersusuan. Ada pula ahli lain yang mengatakan bahwa tiga kali susuan penuhlah yang menjadikan seseorang menjadi saudara sepersusuan dengan orang yang menyusu dari satu ibu. Satu kali menyusu ukurannya adalah menurut biasanya seorang bayi menyusu hingga kenyang, bukan setengguk atau dua tengguk saja. Akan tetapi Hanafi memiliki pendapat bahwa walaupun sedikit itu tetap dihitung satu kali susuan. Mengenai hal ini, Sayuti Thalib berpendapat bahwa satu kali susuan adalah satu kali susuan biasa seorang anak hingga si anak merasa kenyang ${ }^{36}$.

Perihal waktu menyusu itu tidak perlu pada waktu yang bersamaan. Misalnya si C menyusu pada seorang ibu saat suburnya air susu ibunya tahun itu, sedangkan si D menyusu pada tiga tahun lalu pada subur air susu si ibu yang sama. Kebiasaan dahulu kala, dimana golongan bangsawan atau penghuni kota menyuruh seseorang di luar kota yang sehat dan bersih untuk menyusukan anaknya. Tentunya kisah yang paling kita ketahui adalah kisah tentang Rasulullah Saw.

\footnotetext{
${ }^{36}$ Thalib, Hukum Kekeluargaan...., hlm. 52.
} 
Nabi Muhammad Saw disusui oleh seorang perempuan dari luar kota Mekah bernama Halimah, yang kemudian perempuan ibu susu Nabi Saw itu dinamakan Halimah al-Sa'diyah (Siti Halimah yang Berbahagia). Karena sungguh beruntung ia telah menyusui Nabi Saw. Sebelumnya, Rasulullah Saw di kota Mekah disusui oleh seorang wanita bernama Syu'aibah selama beberapa hari. Yang mana Syu'aibah ini juga pernah menyusui paman Nabi Saw yaitu Hamzah bin Abdulmutalib, sehingga Hamzah dan Nabi Saw merupakan saudara sepersusuan.

Era modern saat ini, telah muncul praktik donor ASI di kota-kota besar. Ditinjau dari fikih dan sebagaimana telah diuraikan pada bagian sebelumnya bahwa menyusui diistilahkan dengan ar-radha'. Konsekuensi syar' $i$ dari menyusui bayi orang lain yaitu menjadi haram untuk dikawini. Dalam praktik, Islam menganjurkan supaya memilih ASI dari perempuan yang beragama Islam, memiliki akhlak yang baik, jasmaninya sehat, dan solehah. Imam Malik memakruhkan untuk menerima ASI dari perempuan yang beragama Yahudi, Nasrani, Majusi, dan yang buruk akhlaknya. Hal tersebut dikhawatirkan hal tersebut dapat membawakan perangai buruknya pada si bayi yang disusui walaupun jasmaninya terlihat sehat.

Mengenai donor ASI, para ulama setuju untuk memperbolehkan donor ASI dengan catatan bahwa donor itu mesti secara langsung melalui payudara kepada si bayi. Kebolehan ini berdalil dengan keumuman ayat QS. Al-Maidah (5): 2 "Dan, tolongmenolonglah kamu dalam [mengerjakan] kebaikan dan takwa dan jangan tolongmenolong dalam berbuat dosa dan pelanggaran. ${ }^{37 " ~ K e m u d i a n ~ h u k u m ~ m e n g e n a i ~ j u a l ~ b e l i ~}$ ASI, kebanyakan ulama juga membolehkannya. Hal ini berdasar pada QS. At-Thalaq (65): 6, "Kemudian, jika mereka menyusukan (anak-anak)mu untukmu maka berikanlah kepada mereka upahnya. ${ }^{38 " 39}$

Dengan demikian, walaupun dalam QS. An-Nisa (4): 23 yang disebutkan hanya ibu susuan dan saudara sepersusuan namun lingkupnya tidak terbatas pada yang tersebut

\footnotetext{
${ }^{37}$ Qs. al-Maidah (5): 2.

${ }^{38}$ Qs. at-Thalaq (65): 6

39 https://www.republika.co.id/berita/koran/dialog-jumat/15/05/22/noqm0f6-donor-asi-dalamfikih-islam. Diakses Selasa, 30 Juni 2020, 13.00 WIB.
} 
dalam ayat itu saja. Berlaku juga pada perempuan-perempuan yang lain yang mana telah disebutkan dalam Kompilasi Hukum Islam. Perlu berhati-hati pula akan praktik donor ASI dan jual beli ASI yang ada saat ini, karena harus benar-benar diketahui bagaimana perangai ibu yang akan memberikan susuan tersebut.

\section{Tinjauan Medis Terhadap Perkawinan Saudara Sepersusuan}

Islam memandang ilmu kedokteran sebagai pengetahuan yang mendalam dari hasil kerja keras para ilmuwan muslim atas segala permasalahan duniawi dan ukhrawi yang berlandaskan pada wahyu Allah Swt ${ }^{40}$. Allah dan Rasul-Nya sangat menganjurkan bagi setiap muslim untuk melangsungkan perkawinan apabila telah sanggup secara rohani dan jasmani. Namun perlu juga diperhatikan larangan-larangan perkawinan yang menyebabkan dua orang pria dan wanita tidak dapat melangsungkan perkawinan, salah satu diantaranya adalah hubungan sepersusuan. Tentu, ketentuan larangan ini, tidak semata-mata ditetapkan tanpa alasan oleh Allah Swt. Seperti bukti-bukti ilmiah dari setiap ayat Al-Quran yang lain, ketetapan ini pun menurut penulis memiliki alasan ilmiah mengapa perkawinan sepersusuan dilarang.

Berbagai penelitian mengungkap bahwa dalam Air Susu Ibu (ASI) orang yang menyusui terdapat unsur gen. Implikasi pada yang disusui adalah terbentukanya organorgan pelindung jika dilakukan antara 3 hingga 5 susuan. Dengan demikian hal ini akan membawa sifat khusus si ibu susuan (pemilik ASI) dan saudara sepersusuan lain. Pendapat dr. Jamaluddin Ibrahim, mengatakan bahwa ASI terdiri dari sel-sel induk yang membawa sifat genetik umum untuk ayah dan ibu. Sifat-sifat genetik itu akan berpindah pada anak yang menyusu pada ibu tersebut. Fakta ilmiah inilah yang menguatkan larangan untuk menikahi saudara sepersusuan. Karena apabila perkawinan sepersusuan dilakukan akan berpotensi membuahkan kerentanan atau ketidakseimbangan dalam sistem kekebalan tubuh si bayi serta penyakit genetik serius lainnya ${ }^{41}$.

\footnotetext{
${ }^{40}$ Li’izza Diana Manzil. Urgensi Ilmu Kedoteran Islam dengan Hukum Islam: Studi Identifikasi Deoxrybo Nucleid Acid (DNA) Terhadap Sepersusuan. Hukum Islam Vol.18 No.1 Juni (2018), hlm. 93.

${ }^{41}$ Ibid.
} 
Beberapa kajian ilmiah yang lain menyatakan bahwa dalam ASI terdapat antibodi yang apabila disusukan pada bayi akan memicu atau merangsang terbentuknya antibodi pada tubuh bayi susuan tersebut. Hal ini dapat terjadi setelah beberapa kali susuan, antara tiga hingga lima kali susuan yang mengenyangkan. Ukuran dosis tersebutlah yang harus terpenuhi untuk dapat membentuk antibodi pada manusia. Dalam penelitian percobaan yang dilakukan pada hewan yang sistem kekebalannya belum terbentuk secara sempurna. Saat hewan tersebut menyusu ia mendapatkan beberapa sifat turunan khusus yang bersifat antibodi dari susu yang diminumnya. Selanjutnya ia akan memiliki kemiripan dengan saudara baik laki-laki maupun perempuan sepersusuannya ${ }^{42}$.

Implikasi dari tetap dilakukannya perkawinan sepersusuan mirip dengan perkawinan sedarah yaitu dapat menurunkan generasi yang mempunyai kemunduran tabiat (kecacatan). Karena ketika terjadi perkawinan sepersusuan maka akan hilang sebagian sifat positif dominan dalam kode genetik, yang implikasinya menyebabkan menjadi dominannya sebagian sifat negatif, akibat dari adanya kedekatan pada sifat-sifat genetik saudara sepersusuan yang menikah tersebut. Tentu, hal ini dapat terjadi karena sifat air susu ibu yang menggantikan sebagian gen kekebalan yang dimiliki oleh bayi susunya, warisan gen milik ibu kandungnya. Namun perlu ditambahkan syarat bahwa bayi yang disusui tersebut umurnya belum sampai dua tahun ${ }^{43}$.

Dapat ditarik suatu benang merah bahwa ASI dapat membentuk struktur tubuh di bayi yang disusui, termasuk membuat daging si bayi tumbuh dan membentuk tulang. Ditinjau dari segi medis, gen yang terdapat dalam ASI akan berpindah dari ibu susuan kepada bayi yang disusui sehingga faktor-faktor keturunan, daya imun, dan sifat-sifatnya juga ikut berpindah. Hal inilah yang menyebabkan adanya kesamaan gen antara anak susuan dan ibu susuan. Oleh karenanya, diharamkan untuk dilakukannya perkawinan dengan saudara sepersusuan agar terhindar dari timbulnya hal-hal buruk pada keturunannya atau melahirkan keturunan yang abnormal. Hal penting lainnya adalah

42 https://www.kiblat.net/2017/07/29/inilah-alasan-medis-adanya-larangan-menikahi-saudarasepersusuan/. Diakses Selasa, 30 Juni 2020, 13.00 WIB.

43 Muhammad Hasnan Nahar, Hadis-hadis Larangan Menikahi Saudara Persusuan Kajian Ma'anil Hadis, Skripsi (Yogyakarta: UIN Sunan Kalijaga Sunan Kalijaga, 2016), hlm. 91. 
bahwa sungguh ketetapan-ketetapan Allah yang ada dalam Al-Quran pasti ada hikmah dan bukti ilmiahnya yang kerapkali manusia belum sampai pada tahap menelitinya. Satu catatan penting bahwa tidak ada satu pun hukum dalam Islam kecuali itu membawa kepada kemaslahatan hidup bersama baik di dunia maupun di akhirat.

\section{SIMPULAN}

Larangan perkawinan dibagi menjadi dua yaitu larangan perkawinan untuk selamanya (tahrim muabbad) dan dalam jangka waktu tertentu saja (tahrim muwaqqat). Yang termasuk dalam tahrim muabbad dalam hal ini yaitu larangan perkawinan karena hubungan keturunan (nasab), larangan perkawinan karena telah ada perkawinan sebelumnya (mushaharah), dan larangan perkawinan karena sepersusuan (radha'ah). Larangan perkawinan sepersusuan diatur dalam QS. An-Nisa (4): 23 yaitu larangan untuk mengawini ibu susumu dan saudara perempuan sepersusuan. Namun dalam perkembangan fikih, larangan itu tidak terbatas pada dua subjek yang disebutkan dalam ayat tersebut.

Larangan perkawinan sepersusuan apabila dilihat dari sudut pandang laki-laki maka yang dilarang dikawini oleh pria karena sepersusuan ialah menikahi 1) wanita yang menyusuinya dan seterusnya ke atas; 2) wanita sepersusuan dan seterusnya ke bawah; 3) wanita saudara dan kemenakan sesusuan seterusnya ke bawah; 4) wanita bibi sesusuan dan nenek bibi sesusuan seterusnya ke atas; dan 5) anak yang disusui oleh isterinya dan keturunannya. Ulama berpendapat larangan perkawinan sepersusuan atau radha'ah jika sampainya air susu ibu susuan ke dalam perut si bayi yang belum mencapai usia dua tahun kalender hijriyah. Mengenai berapa kali bayi tersebut dapat dikatakan menjadi saudara sepersusuan, penulis memakai pendapat 3 hingga 5 susuan yang mengenyangkan.

Ditinjau dari segi medis atau kedokteran, perkawinan sepersusuan dapat menghasilkan keturunan atau generasi yang mempunyai kemunduran tabiat (kecacatan). Karena ketika terjadi perkawinan sepersusuan maka akan hilang sebagian sifat positif dominan dalam kode genetik, yang implikasinya menyebabkan menjadi dominannya 
sebagian sifat negatif, terjadi karena kedekatan sifat-sifat genetik saudara sepersusuan yang menikah tersebut. Dengan demikian bahwa segala ketentuan yang Allah Swt tetapkan memiliki bukti ilmiah mengapa perkawinan sepersusuan dilarang, hal ini untuk menghindari keturunan yang cacat.

\section{DAFTAR PUSTAKA}

Ali, M. D. (1997). Hukum Islam dan Peradilan Agama. Jakarta: PT RajaGrafindo Persada.

Ali, Z. (2007). Hukum Perdata Islam di Indonesia. Jakarta: Sinar Grafika.

Al-Jaziri, A. (1986). al-Fiqh 'ala Madzahib al-Arba'ah. Beirut: Dar al-Fikr.

Al-Malibrary, Z. b. (1979). Fatchul Mu'in. Kudus: Menara Kudus.

Al-Ra'uf, D. (2011). Aturan Pernikahan dalam Islam. Jakarta: Jal Publishing.

Cahyono, A. B., \& Sjarif, S. A. (2008). Mengenal Hukum Perdata. Jakarta: CV Gitama Jaya.

Dahlan, A. A. (1996). Ensiklopedi Hukum Islam. Jakarta: Ikhtiar Baru Van Hoeve.

Djubaedah, N., Lubis, S., \& Prihatini, F. (2005). Hukum Perkawinan Islam di Indonesia. Jakarta: PT Hecca Mitra Utama.

Fakhruddin. (2017, July 29). Inilah Alasan Medis Adanya Larangan Menikahi Saudara Sepersusuan. Retrieved from Kiblat: https://www.kiblat.net/2017/07/29/inilahalasan-medis-adanya-larangan-menikahi-saudara-sepersusuan/

Hafidzi, A., \& Safrudin. (2015). Konsep Hukum Tentang Radha'ah Dalam Penentuan Nasab Anak. Khazanah: Jurnal Studi Islam dan Humaniora, 283-317.

Hermanto, A. (2017). Larangan Perkawinan Perspektif Fikih dan Relavansinya dengan Hukum Perkawinan di Indonesia. Muslim Heritage, 125-152.

Imran, R. (2018). Larangan Kawin Karena Pertalian Sesusuan dalam Perspektif Fikih dan Kompilasi Hukum Islam. Tathwir Jurnal Pengembangan Masyarakat, 28-36.

Indonesia. Undang-Undang Perkawinan, UU No.1 Tahun 1974, LN No.1 Tahun 1974, TLN No. 3019.

Indonesia. Peraturan Pemerintah tentang Pelaksanaan Undang-Undang Nomor 1 Tahun 1974 tentang Perkawinan. PP No. 9 Tahun 1975.

Indonesia. Instruksi Presiden tentang Kompilasi Hukum Islam. Inpres No. 1 Tahun 1991.

Manzil, L. D. (2018). Urgensi Ilmu Kedoteran Islam dengan Hukum Islam: Studi Identifikasi Deoxrybo Nucleid Acid (DNA) Terhadap Sepersusuan. Hukum Islam, 78-99. 
TAHKIM, Jurnal Peradaban dan Hukum Islam. Vol.3 No.2 (0ktober, 2020) | ISSN : 2597-7962

Moleong, L. J. (2011). Metode Penelitian Kualitatif. Bandung: Remaja Rosda Karya.

Nahar, M. H. (2016). Hadis-hadis Larangan Menikahi Saudara Persusuan Kajian Ma'anil Hadis, Skripsi. Yogyakarta: UIN Sunan Kalijaga Sunan Kalijaga.

Nisa, K. (2017). Analisis Hukum Islam Terhadap Larangan Perkawinan Yang Dilaksanakan Pada Tahun Duda (Studi Kasus di Desa Pilangrejo Kecamatan Juwangi Kabupaten Boyolali, Skripsi. Semarang: UIN Walisongo.

Nuruddin, A., \& Tarigan, A. A. (2006). Hukum Perdata Islam di Indonesia: Studi Ktiris terhadap Perkembangan Hukum Islam dari Fikih. Jakarta: Prenada Media Group.

Putra, H. (2015, May 22). Donor ASI dalam Fikih Islam. Retrieved from Republika: https://www.republika.co.id/berita/koran/dialog-jumat/15/05/22/noqm0f6-donorasi-dalam-fikih-islam

Ramulyo, M. I. (1996). Hukum Perkawinan Islam: Suatu Analisis dari UU No. 1 Tahun 1974 dan Kompilasi Hukum Islam. Jakarta: Bumi Aksara.

Soekanto, S., \& Mamudji, S. (1985). Penelitian Hukum Normatif, Suatu Tinjauan Singkat. Jakarta: Rajawali.

Subekti. (1984). Pokok-Pokok Hukum Perdata. Jakarta: PT Intermasa.

Sudarsono. (1997). Hukum Keluarga Nasional. Jakarta: Rineka Cipta.

Thalib, S. (1986). Hukum Kekeluargaan Islam. Jakarta: UI-Press.

Umam, K., \& Pramukti, A. S. (2015). Hukum Islam dan Acara Peradilan Agama. Tangerang Selatan: Universitas Terbuka.

Wibisana, W. (2016). Pernikahan dalam Islam. Jurnal Pendidikan Agama Islam - Ta'lim, 185-193. 